\title{
Keep That Lane Open!: Race, Space, and Mardi Gras in Kansas City
}

\section{Peter A. Williams \\ Introduction: Keep That Lane Open!}

In a small, densely packed back room of the art gallery in the Crossroads Arts District of Kansas City, local Afro-funk band Hearts of Darkness played a vibrant, throbbing set of songs as bodies pulsed, jumped, and surged with the music. Both band and audience were garishly costumed, ranging from sequined prom gowns and suits embellished with feathers and epaulets to simple dime-store masks in purple, green, and gold. Outside in the alley, the members of various "krewes" put the final touches on their floats-homemade, eclectically and erratically decorated, none of them bigger than a small-sized sedan. As the band's set ended, emerging sweaty from the back room, I stood on the sidewalk outside the gallery taking photographs and video as the floats and marchers poured out of the alley and on to $18^{\text {th }}$ Street to start the parade. Members of Hearts of Darkness joined their krewe under a banner emblazoned with the krewe's name-_Top of the Bottoms"-and the slogan, "Always for Pleasure."

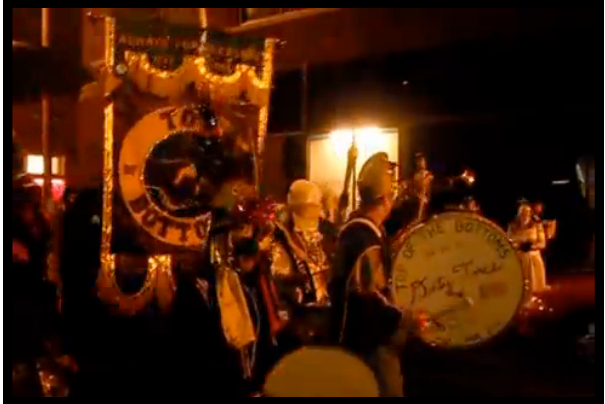

Click image above to watch video, "When the Saints."

[Click here to read a transcript of the video (also located at the bottom of this article).]

I joined the marchers in the street, switching audio, video, and photographic recording devices in and out of my pockets as I walked, sang, and danced with the crowd. The parade proceeded east on $18^{\text {th }}$ Street, with at least 100 participants, many in costume, many with instruments-trumpets, saxophones, guitars, bass and snare drums, washboard, flutes, and hand percussion. Informally organized versions of "lko Iko" and "When the Saints Go Marching In" played up and down the loose column of people, led mostly by the drummers in the Top of the Bottoms krewe. Parade leaders, dressed in bright colors and carrying feathered fans, occasionally herded participants into the right lane of the street so that cars could pass by on the left. Their cries of "Keep that lane open!" helped warn paraders when cars were trying to pass.

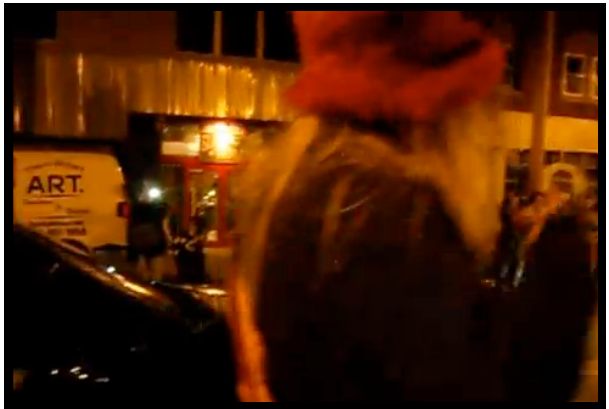

Click image above to watch video, "Keep That Lane Open."

[Click here to read a transcript of the video (also located at the bottom of this article).] 


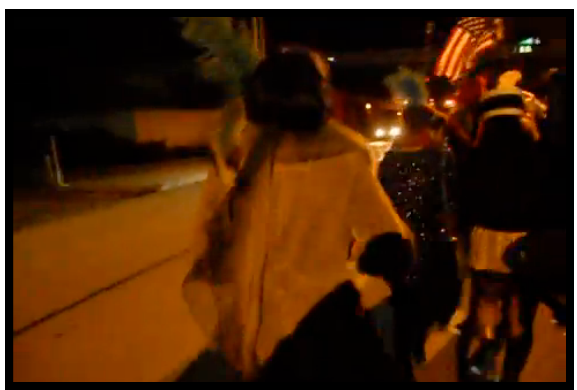

Click image above to watch video, "Washboarding and Keeping That Lane Open." [Click here to read a transcript of the video (also located at the bottom of this article).]

Out in front of the whole throng, an African American woman in her twenties performed a version of the cakewalk, bouncing, crouching low and walking, swerving, and sliding in front of the group.

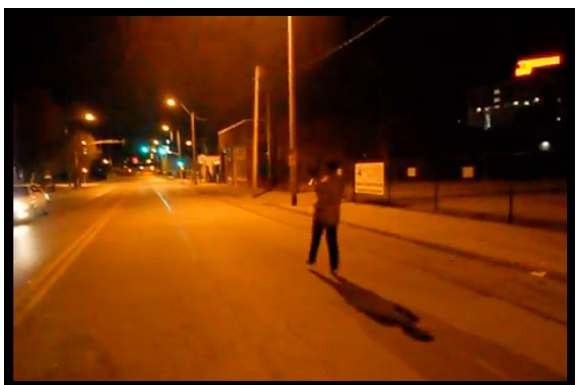

Click image above to watch video, "Dancing in Front of the Parade."

[Click here to read a transcript of the video (also located at the bottom of this article).]

She wore black jeans, sneakers, a large, gray, men's sport coat, and a black baseball hat turned sideways. Marchers were mostly young women and men in their 20 s and 30 s (with a few in their 40 s and 50 s, and some children) and a mix of whites and people of color, with the white participants predominating.

There was no police escort or official presence of any kind to protect or harass the parade, as far as I could tell. The presence of open liquor containers and marijuana smoke seemed to confirm the sense that police would not be involved. The parade marched down a mostly deserted street, near empty warehouses and office buildings closed for the day, and past the occasional art gallery or bar. When the group reached the overpass of US Highway 71, a cheer went up and the musicians played louder, taking advantage of the cathedral-like acoustics under the cement and steel structure to amplify their sound.

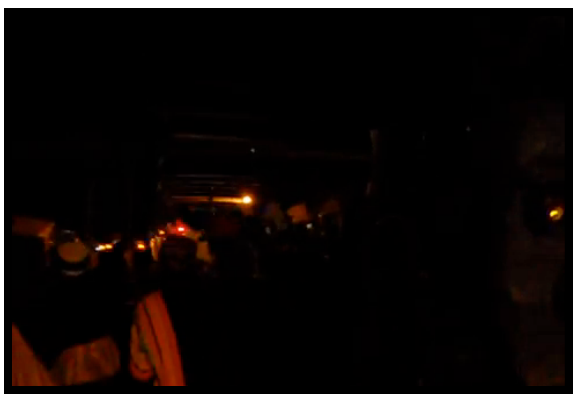

Click image above to watch video, "Under the Overpass."

[Click here to read a transcript of the video (also located at the bottom of this article).]

The noise echoed as the parade crossed Troost Avenue and passed by empty parking lots, a small park, and several car dealerships. Another cheer went up as we neared the intersection of $18^{\text {th }}$ and Vine, the historic Kansas City Jazz District and the parade's terminus at the jazz club, the Blue Room. The marchers pooled in front of the Blue Room as we squeezed into the front door of the club one at a time. Inside, the marchers filled the club to near capacity and the instrumentalists took the stage, joining with the Serendipity Brass Band, whose set was already in progress. 
This underground Mardi Gras parade took place on the evening of Tuesday, February 21, 2012. It was organized by Kansas City trumpeter Bob Asher, a member of the multicultural Afro-funk hip-hop band Hearts of Darkness. In 2000, Asher founded The Top of the Bottoms Social Club, based on New Orleans social aid and pleasure clubs and named after the Kansas City working class and bohemian neighborhood, The West Bottoms. Through Top of the Bottoms (TOB), Asher organized yearly carnival events in Kansas City, especially masquerade balls that featured local music (Anderson). The parade I attended in 2012 included other locally organized social clubs, floats, a parade, and brass band music - aspects of both black and white Mardi Gras parades in New Orleans. This essay discusses the TOB Mardi Gras parade as shaped by a network of globally circulating images of Mardi Gras in New Orleans in the twentyfirst century, the history of race and space in Kansas City, and the intercultural exchange involved in white performances of black cultural practices as they move from the "circum-Caribbean" city of New Orleans to the U.S. heartland of Kansas City. The parade is a partially improvised performance of a historical narrative linking Kansas City's mostly white bohemian arts culture in the present to the city's past as a major jazz city and center for African American culture. It is a narrative told by bodily movement through urban space and through improvised sound and dance, and it demonstrates the complex social relations that are highlighted when a cultural form is subject to crosscultural communication, borrowing, and appropriation.

The parade takes a particular route, pre-planned, down a straight urban street, but it also has improvised aspectsbody movement improvised much in the way as social dance; rough, spontaneous arrangements of two well-known songs; and the self-policing gesture of "keep that lane open." Participants include professional and amateur musicians, each improvising arrangements of the only two songs that were played, "Iko Iko" and "Saints." The paraders strutted, high-stepped, marched in time, and otherwise danced down the street, a collective movement that also featured individual creative freedom. The unofficial slogan of the underground parade, "Keep that lane open," serves to keep the parade hemmed in, lest the revelry and chaos get "out of control." It provides an improvised, provisional order that helps stave off police harassment and keeps the parade from blocking traffic, which would almost surely attract negative police attention.

Furthermore, it is an act of self-discipline, an aspect of improvisation that often gets left out of discussions of its social meanings, but that improvising musicians like Sun Ra valued. For Ra, discipline makes improvisation possible and is the necessary flip side to freedom. As he claimed, discipline "ought to permit people to find the most natural things. Without the base, total freedom is impossible. Everything needs roots" (qtd. in Szwed 115). The TOB Mardi Gras parade's practice of "keeping the lane open" is a kind of disciplined practice of improvisation that Ra seems to argue for. In the moment, it changes the direction and flow of a crowd of people dancing down the street, accommodating other everyday street traffic through the voluntary shifting of group momentum. It also means individuals must disrupt their flow of dancing in order to stay out of the left lane, to allow everyone to fit into the right lane and to not bump into other marchers too much. "Keeping the lane open" is an accommodation to the everyday aspects of the street, leaving space for others to move outside of the parade if they wish. This kind of self-discipline in an improvised group setting combines aspects of several different Mardi Gras parades: the community building of African American Mardi Gras parades and second lines, the "love and theft" of mostly white appropriations of Mardi Gras, and the subversive potential and utopian ideals of carnival celebrations all over the world.

\section{Mardi Gras ${ }^{\mathrm{TM}}$}

The major Mardi Gras celebrations in New Orleans today have their roots in carnival celebrations brought to the New World by European colonizers, celebrations that were themselves based on centuries-old carnival practices in ancient Greek and Roman cultures and the medieval Catholic church's liturgical calendar. Creoles in New Orleans in the $18^{\text {th }}$ and $19^{\text {th }}$ centuries adapted and changed some of these traditions to better suit the complex identity of the city. In the mid-19 ${ }^{\text {th }}$ century, exclusively Anglo-American "krewes" (formed by secret societies of New Orleans's elites) began appearing, and these came to dominate Mardi Gras celebrations until the 1990's, when the city council forced the krewes to make their records public and to desegregate their ranks.

The smaller, mostly black Mardi Gras parades that feature "tribes" of Mardi Gras Indians have their roots in a host of intercultural interactions, growing out of the circulation of West Africans, Caribbean peoples, Native Americans, and Europeans facilitated by the slave trade in the seventeenth through nineteenth centuries, a phenomenon that Joseph Roach calls the "circum-Atlantic" (4-7). The roots of New Orleans black Mardi Gras celebrations in the Bahamas, Haiti, Cuba, and other Caribbean cultures, as well as its retaining of West African elements, has also been well documented. ${ }^{1}$ Native American cultures also have some influence on the Mardi Gras Indians. Oral tradition says that the Native Americans in the area took in escaped slaves from New Orleans in the $19^{\text {th }}$ century and that the elaborate feathered costuming and tribe names are a tribute to that intercultural connection (Roach 202-11). 
While these histories help explain the intercultural origins of Mardi Gras in New Orleans, they do not fully explain the origins of the Top of the Bottoms Mardi Gras parade in Kansas City. Another explanation for how this cultural practice came to be in Kansas City in the $21^{\text {st }}$ century involves the ever-increasing circulation of commodities, cultural practices, and people since the late $20^{\text {th }}$ century-that is, globalization. Of course, the existence of Mardi Gras in New Orleans and the Mardi Gras Indians is proof that such circulation was happening long before scholars noticed it and gave the phenomenon a name. But I contend that the TOB Mardi Gras parade would not be possible without the global branding of New Orleans as a party town and the exportation of images of the Mardi Gras celebration associated with it.

In Authentic New Orleans: Tourism, Culture, and Race in the Big Easy, Kevin Fox Gotham examines the history of the branding of New Orleans by studying tourism in the city. Rather than look at the effects of globalization on tourism as either mostly bad or mostly good for a city's cultures, he instead "views tourism as an amalgam of both homogenizing forces of sameness and uniformity, and diversifying forces of difference and hybridity"-tourism from "above" and "below"-in order to "get a better sense of how tourism can promote as well as destabilize and undermine local traditions and cultures" (7). Certainly, New Orleans's unique cultures have been featured in globally circulated media like plays, novels, recordings, newspapers, and journals since the Louisiana Purchase (and before). Gotham argues, however, that beginning in the 1990s various institutions have acted in concert "through a series of strategic branding campaigns that aim to define New Orleans as America's 'most authentic city.' Such campaigns are employed synergistically to maximize exposure of New Orleans to a global audience" (135). Visitors bureaus, multinational corporations, and individual private and public actors have worked together-willingly or not-in creating New Orleans as a global brand, with Mardi Gras as one of its key features. Gotham also adds to this list the building of sports arenas and museums, the hosting of national sporting events, and the World's Fair in 1984 (14).

I would add to this group the increasing number of films, television programs, documentaries, and books about New Orleans, especially since Hurricane Katrina in 2005, which emphasize the city's "authenticity." The popularization nation-wide of New Orleans culture in the aftermath of Hurricane Katrina brought about a wider discussion in the U.S. about race and class, public works, and tourist culture. The receding floodwaters revealed national, state, and local disinvestment in public safety and infrastructure, not to mention the continued spatial segregation of poor and working class African Americans. Questions of urban space also entered into this discussion as different parties wondered how, why, and for whom the city would be rebuilt, not to mention whether displaced residents could or would return. It also brought national attention to neighborhoods that many non-residents (mostly white) had never heard of before, like the Lower Ninth Ward and Tremé. Documentaries like Spike Lee's When the Levees Broke helped highlight these issues, and David Simon's fictional series Tremé, set in post-Katrina New Orleans, celebrated several aspects of New Orleans culture, especially music, while also addressing systemic issues like police brutality, unfair housing practices, and exclusionary real estate development.

Gotham also notes that marketing strategies emphasizing authenticity rely on the "holy trinity" of New Orleans culture-history, music, and food, of which music is the primary export (137-39). While Gotham mentions the founding of the New Orleans Jazz Orchestra in 2002 as pivotal in the exporting of New Orleans music, he could have also mentioned the central place given to New Orleans in Ken Burns' television documentary, Jazz, in 2000, which featured New Orleans musician Wynton Marsalis as a primary informant on the music's history. And since its founding in 1970, the New Orleans Jazz and Heritage Festival has done much to promote and export New Orleans music throughout the globe. Gotham further argues that the effects of this global branding are inescapable. Local reinventions of Mardi Gras traditions that try to subvert the dominant narrative in New Orleans both depend on it and try to undermine it: "On the level of the capacities of local actors, the homogenizing and standardizing forces of tourism from above are embedded in the practical consciousness of residents and provide the stocks of knowledge they draw on to produce new cultural forms" (206).

Although Gotham is primarily concerned with the effects of the marketing of the city on notions of "authenticity" within New Orleans, I am most interested presently in its effects in other places-how these manufactured images get picked up and deployed locally in other urban areas. The founders of the Kansas City underground Mardi Gras parade, not many of them over 40 years old, grew up and matured in this widening global awareness of New Orleans as an "authentic" city of music; as I will discuss below, they deploy the associated images of the city in a performance of Mardi Gras that emphasizes creativity, experimentalism, global politics, and communal music-making.

\section{Building Walls and Bridges}

Many of the participants in the parade are involved in various creative practices in Kansas City, as visual artists, gallery owners, dancers, performance artists, costumers, and musicians playing jazz, rock, Afro-funk, hip-hop, and other improvised music. They create their art in the context of a history of uneven real estate development, 
institutional racism, de facto segregation, poverty, exploitation, and ever increasing spatial, cultural, and ideological divides between whites and non-whites in Kansas City. The participants were born between 1970 and 1990, roughly, and they have grown up with spatial segregation based on race in Kansas City (or other cities across the US) as an established reality, a background fact to their lives. The history of that segregation shaped the relationships, sound, and movement in which these artists participate.

As Gotham's comprehensive study of race and real estate in Kansas City points out, between 1969 and 1974 , most of the funds the city received from the federal government through the 1968 Housing Act went toward building new units in suburban areas. Section 235 of the Housing Act enabled opportunistic real estate developers to sell houses with only cosmetic rehabilitation to low-income buyers, who could not afford to pay for the subsequent repairs and structural upgrades these houses needed. To counteract the effects of the Housing Act, some neighborhood associations recognized the value of Kansas City's diverse neighborhoods and encouraged families, especially white families, to remain in areas of higher diversity instead of selling their inner-city homes and moving to the suburbs in a panic. By 1973, enough local and regional action had been taken against unjust real estate practices across the country to force the US government to place a moratorium on all federally subsidized housing programs. Without the backing of government loans, however, real estate developers and brokers stopped working in inner city neighborhoods altogether (Gotham, Race 127-138). This meant that in Kansas City, as Gotham notes, "private lending agencies ceased making home mortgage money available to residents living east of Troost Avenue, thereby redlining entire neighborhoods and launching a vicious wave of disinvestment and physical deterioration that continues to this day" (138). These practices led to the creation of what is known locally as the "Troost Wall," because of the way the street serves as a distinct and persistent barrier between the mostly upper class white neighborhoods to the west and the mostly poor and working class African American neighborhoods to the east.

Federal policies since the 1970s have only reinforced the Wall. As Gotham notes, the 1980s and 1990s saw a "twodecade long transformation of federal housing policy that has included ... drastically reducing federal spending on housing" (139). While these practices were not overtly racist, they resulted in many more black families being concentrated in areas east of Troost Avenue, and more and more white families moving to the Kansas City suburbs in recent decades. These private real estate practices and public housing policies shape, and are shaped by, shifting yet persistent notions of race, "racial ideologies, beliefs, and institutional practices," that, Gotham notes, "have become more invisible and covert" (150). The Top of the Bottoms Mardi Gras parade took place in these contexts, as part of the material, spatial, and ideological realities of living in Kansas City in the early $21^{\text {st }}$ century. These performers, most of them white, would have the privilege of ignoring these realities in their everyday lives, but the fact that they perform various forms of black music, sometimes with non-whites, and in spaces all over the Kansas City area, means that they may be more aware of racial divides than whites not associated with jazz or other performances in Kansas City.

The participants in the underground Mardi Gras parade in Kansas City have also grown up in the context of crossracial coalitions in Kansas City, like the neighborhood associations in the early 1970s that Gotham mentions (13436). Recent efforts by community members who have experienced and studied the history of racial and spatial separation in Kansas City symbolized by the Troost Wall have sought to revitalize the area, to metaphorically tear down the Wall and build a bridge that could help to create a diverse inner-city core once again. In 2012, two organizations, the Green Impact Zone of Missouri and Brush Creek Community Partners, hosted an event to celebrate these efforts, exemplified by the building of the "Troost Bridge" over Brush Creek at $48^{\text {th }}$ Street and Troost Avenue (Green Impact Zone of Missouri). The event, a free street festival on the bridge itself, was called "Meet Me at the Bridge." The festival's organizers recognized the symbolism of the Troost Wall in Kansas City history: "For years, Troost Avenue has been symbolic of some of the division in our community. With this street festival, we'll celebrate how it connects us-north and south, east and west, black and white" (Green Impact Zone of Missouri).

Significantly, the event featured local jazz from established mainstream artists David Basse, Bobby Watson, and Book of Gaia. Local jazz writer Bill Brownlee counted about 250 people at the event, which also featured speeches by "a host of politicians, community organizers, educators, environmental advocates and representatives of neighborhood associations," but he noted that the festival was a community event "that just happened to feature jazz" (Brownlee). One local musician I spoke to, trumpeter Hermon Mehari, performed with Bobby Watson's group and remembers the audience being fairly racially diverse though heavily skewed toward middle aged and older Kansas Citians (Mehari). While Brownlee might see jazz as coincidental to the community event, I suggest that it is indeed significant, as a demonstration of this particular group's belief that jazz has to do with race and place. Presenting a jazz performance at this event signifies that at least some community leaders in Kansas City today recognize that jazz can and has crossed racial lines, and that the sounds of jazz are also intimately tied to specific spaces in Kansas City. In some ways, this is the implicit argument of the TOB Mardi Gras parade, which does cross Troost Avenue on its way to the $18^{\text {th }}$ and Vine Jazz District. 


\section{Appropriating Carnival Time}

A much larger, highly advertised, and corporate-sponsored event took place in Kansas City the Saturday before Mardi Gras 2012 at the Power and Light District, a former industrial center in Kansas City's downtown that has been recently renovated into an upscale entertainment area with bars, restaurants, shopping, and nightclubs. This event made heavy use of the streamlined and packaged Mardi Gras brand that circulates globally, featuring costuming in purple, green, and gold; excessive drinking; and the ubiquitous plastic bead necklaces. In contrast to TOB's creative use of Mardi Gras images, the event at the Power and Light District represents use of the Mardi Gras brand by the multinational corporations that sponsored the event and the nationally owned radio station franchises that promoted it. In these ways, it seemed related to the major Mardi Gras parades in New Orleans, except there was no parade, no social clubs, and little family-friendly activity.

The Power and Light District caters to middle and upper class patrons, and until recently, strictly enforced a dress code that excluded some African Americans. The code, established by the commercial real estate leaders who developed the Power and Light District, forbids "sleeveless shirts on men; profanity on clothing; sweat pants or full sweat suits; bandanas; exposed undergarments on men; [and] excessively long shirts" ("Frequently Asked"), all styles associated with hip-hop apparel. The language of the code is especially directed toward young African American men, whose bodily presence would ostensibly endanger the image of middle class white respectability that the District seeks to promote. The dress code was challenged in court in 2010 and is no longer strictly enforced, but the code is still intact and the message of exclusion remains. This development of racialized space in the Power and Light District continues the racist real estate practices that Gotham describes as shaping the character of Kansas City and its suburbs. The Top of the Bottoms' Mardi Gras parade may not be so overtly exclusionary, but the power relations based on race that it highlights are just as vexed.

Some scholarship on carnival time parades discusses their potential to build communities, shape new subjectivities, and subvert cultural norms. These parades retake urban spaces that had been territorialized through urban development, interstate highway construction, urban renewal programs, and the rezoning of neighborhoods into warehouses and other commercial spaces for large corporate use. Such parades repurpose that space for communal activity, pleasure, fun, noise, creativity, and the movement of bodies on the street. They subvert the alienating spaces of industrial warehouses, chain hotels, tourist spots, and government buildings and create community connection, reminding those in the community of their ties to each other, playing them out in movement and music from house to house, from location to location. ${ }^{2}$

These groups play on the idea that the carnival has the potential to critique power structures, much as literary critic Mikhail Bakhtin argued. Carnival time, for Bakhtin, was a period of free, open, boundless communication and expression, a respite from or relaxing of the rigid social order that determined social behavior during "official time." Carnival time is characterized by humor, joviality, excess, free movement, equality among classes of people, and most of all, laughter, while official time is much more regulated, serious, and authoritarian. Carnival consists of a total but temporary overturning of the usual rules, customs, and hierarchies of everyday, official life (Bakhtin 7-9). In his study of Mardi Gras Indians in New Orleans, George Lipsitz elucidates the ways that this African American cultural practice differs from other carnival practices around the world. The Mardi Gras Indians' street performance-which includes elaborate costuming, call-and-response chants, and street marching-does not portray a temporary reshuffling of social roles that relieves pressure and expresses longing for a better world, as in the European-based carnivals that Bakhtin describes. Rather, Lipsitz argues, it is a representation of the realities of everyday existence in working class black neighborhoods. "Their art stems less from ancient story-telling traditions or aesthetic intentions than from the necessity imposed upon them by oppressive social conditions. Their utopian projects originate less from abstract images of an ideal future than from a determination to read the lessons of solidarity and struggle from the past and present into the future." These performances represent a community that creatively balances folk and commercial culture, America and Africa, resistance and accommodation; that representation takes the form of a collectively authored historical narrative and creatively constructs a group identity (235).

The TOB Mardi Gras parade displays many of the elements of the carnivalesque reshuffling of power relations and utopian potential that Bakhtin says are present in most carnival celebrations, as well as some of the subversive potential of black Mardi Gras parades. The TOB parade reappropriates the spaces of downtown Kansas Citywarehouses, rarely used streets, office buildings_-for pleasure and fun. It critiques the use of city streets for the sole purpose of commercial or personal vehicle transport, calling into question the ideology that separates bodies in space according to racial and class taxonomies. It also critiques the corporatization of public events, juxtaposing the commercialized and racially policed Mardi Gras celebration in the Power and Light District with its own freer, more communitarian and somewhat multicultural event. The better future it embodies is one where people can freely and safely walk down deserted city streets at night, making whatever noise they wish collectively, without individual and 
communal pleasure being co-opted by commercial culture. And they do this in a collective, participatory, improvised performance of sound and movement. The parade has no audience and includes professional and amateur musicians, artists, art patrons, and other non-professionals who belong to this small community of creative young people in Kansas City. The young whites, African Americans, and other people of color participating in the underground Mardi Gras parade may demonstrate shifts in multicultural relations and raced identities, building crosscultural coalitions that attempt to understand the history that shaped them, creating cultural hybrids, and performing an embodied crossing of racial lines en masse.

The TOB parade also comprises a historical narrative that helps the paraders construct a collective identity. The marchers' movements (and the sounds they make) connect them to each other, and their movements through particular spaces connect their practices in the present to Kansas City's jazz past. The parade line is thus also a line of historical narrative, telling a particular story about jazz history, art, and movement, in Kansas City as it moves from the bohemian and artsy Crossroads District to the historic $18^{\text {th }}$ and Vine District and the Blue Room jazz club. It allows the young, multiethnic (but predominantly white), creative, and bohemian participants to acknowledge the importance of Kansas City's jazz scene spaces to their own lives, past and present. It connects the two areas of town that have been separated by history, "urban renewal" programs, white flight, and interstate construction. The cheers that go up as the parade passes underneath US Highway 71 and over Troost Avenue are a kind of recognition of that past and the hope that those connections may again be made. It is a carnivalesque celebration of a future in which space is not so rigidly or insidiously regulated along racial lines.

Its similarities to Mardi Gras Indian practices, however, end there. The participants largely don't experience the same material realties of everyday life as Mardi Gras Indians-they come from middle class, mostly white neighborhoods in Kansas City. So, while the form of the parade may borrow from Mardi Gras Indian rituals in many ways, it also owes allegiance to mainstream "white" Mardi Gras celebrations in New Orleans. The translation of both of these cultural practices to different urban spaces and through different bodies changes their meanings. Helen Regis, in her work on New Orleans second line practices, critiques the appropriation of black Mardi Gras practices for use in commercial, mostly private and largely white, settings. These displays draw a distinct line between audiences and performers, with most of the (white) audience members, Regis argues, being unaware of the origins of these practices in the city's black neighborhoods. "What is ironic," she continues, "is that this minstrel-like appropriation of black cultural tradition by the city's elites and the tourism industry goes without any acknowledgement of the popular black tradition on which it is based" ("Second Lines" 475). The unmooring of the parade from its cultural origins leaves the impression that the parades are simply about "pleasure" or just for "partying." Furthermore, this disconnection from the parades' contexts elides the real, material experiences of black Mardi Gras participants and the social relations the parade reproduces (475).

Certainly, the largely white, middle class appropriation of these practices in Kansas City runs the danger of overemphasizing the "party" aspects of Mardi Gras and second line practices, especially since the TOB's slogan is "Always for Pleasure." It is entirely possible that some participants join the parade for this reason, blissfully unaware of the practice's origins. I would suggest, however, that the route of the parade belies a particular intention of the organizers and marchers to make a public statement about race, space, and creativity in Kansas City history, an intention that goes beyond its effects as simply a bit of (marginally disruptive) fun. And it seems to exist in contrast to the large commercial celebration of Mardi Gras in Kansas City's Power and Light District. While TOB's appropriation of black Mardi Gras may not be as egregious as the large commercial or private displays Regis critiques, it is nonetheless an appropriation by a mostly white group of performers of a largely African American cultural practice. Much of the power of the African American Mardi Gras parades gets lost in translation as it moves from one urban spatial context to another and from one group of bodies to another, and some of it is retained, even if only in potential form.

\section{Conclusion: Keeping Lanes Open}

The TOB Mardi Gras parade is a performance of a narrative of jazz history, using sound, movement, space, and carnivalesque humor to connect the past with the present. From the trendy Crossroads Arts District to the $18^{\text {th }}$ and Vine Jazz District, the parade is a performance of that narrative as a direct link from the experimental arts scene in the present to Kansas City's jazz past. As I have argued, that connection is not so clearly or easily made, fraught as it is with the history of spatial segregation in Kansas City. The narrative always leaves someone out, even as it tries to "keep that lane open" for a multitude of voices. In trying to connect Kansas City's mostly white experimental scene with its mostly black jazz history, the TOB attempts an intercultural connection with that past, while also connecting the resistant cultures of African Americans in New Orleans and Africans in the Caribbean with the resistant cultures of mostly white underground performance, visual art, and music. It attempts this by appropriating images of Mardi 
Gras-its subversion of power, carnivalesque humor, and emphasis on the body and pleasure as sites of performative resistance.

While the parade does not have explicit political goals, it does form a temporary and shifting community through improvised sound and movement that has the potential to demonstrate new social relations. This multiethnic group, dominated by whites, demonstrates at least some intercultural relationships through improvised performances and the reappropriation of urban space. It also recognizes the importance of local history, jazz, and African American culture to its own creative and improvisatory aspirations. It pays tribute to that connection by marching to the historic $18^{\text {th }}$ and Vine Jazz District and filling with patrons its most popular and historically important nightclub, the Blue Room. The loosely organized, joyful, egalitarian, improvised music and movement that are essential to the parade are carnivalesque elements that suggest better social relations for a future that recognizes difference. This performance of a more just future, however, takes place in the present that is itself shaped by the history of racialized space in Kansas City. I have also attempted to keep that other lane open in my own analysis, arguing for interpretations of both the subversive, community building, and utopian aspects of the parade on the one hand, and the appropriating, hegemonic aspects on the other. I hope to keep this lane open (to interpretation), because it is the space between love and theft where complex cross-cultural exchanges shape and are shaped by constantly shifting power relations.

\section{Notes}

${ }^{1}$ See Hirsch and Logsdon, Nicholls, and Schindler. On West African influences, see Irobi and Hall.

${ }^{2}$ See Guillory; Lipsitz; Regis, "Blackness"; Roach; and Sakakeeny.

\section{Works Cited}

Anderson, Barry. "The Top of the Bottoms Is Ketchup City's Mardi Gras Breakdown." The Pitch, 22 Feb. 2011, http://www.pitch.com/news/article/20595359/the-top-of-the-bottoms-is-ketchup-citys-mardi-gras-breakdown.

Bakhtin, M. M. Rabelais and His World. M.I.T. Press, 1968.

Brownlee, Bill. "Review: The Meet Me at the Bridge Festival." Plastic Sax, Blogger, 7 May 2012, http://plasticsax.blogspot.ca/2012/05/review-meet-at-bridge-festival.html.

"Frequently Asked Questions." Kansas City Power \& Light District, http://www.powerandlightdistrict.com/index.cfm?page=info.

Gotham, Kevin Fox. Authentic New Orleans: Tourism, Culture, and Race in the Big Easy. New York UP, 2007.

---. Race, Real Estate, and Uneven Development: The Kansas City Experience, 1900-2000. State U of New York P, 2002.

Green Impact Zone of Missouri. "Troost Avenue Bridge Festival." Mid-America Regional Council, http://greenimpactzone.org/festival/.

Guillory, Monique. "Black Bodies Swingin': Race, Gender, and Jazz." Soul: Black Power, Politics, and Pleasure, edited by Monique Guillory and Richard C. Green, New York UP, 1998, pp.191-215.

Hall, Gwendolyn Midlo. "The Formation of Afro-Creole Culture." Creole New Orleans: Race and Americanization, edited by Arnold R. Hirsch and Joseph Logsdon, Louisiana State UP, 1992, pp. 58-87.

Hirsch, Arnold R., and Joseph Logsdon, editors. Creole New Orleans: Race and Americanization. Louisiana State UP, 1992.

Irobi, Esiaba. "What They Came With: Carnival and the Persistence of African Performance Aesthetics in the Diaspora." Journal of Black Studies, vol. 37, no.6, 2007, pp. 896-913. 
Lee, Spike, director. When the Levees Broke: A Requiem in Four Acts. Forty Acres and a Mule Filmworks, 2006. $\mathrm{HBO}$.

Lipsitz, George. Time Passages: Collective Memory and American Popular Culture. U of Minnesota P, 1990, pp. 23353.

Mehari, Hermon. Interview. By Peter A. Williams. 21 May 2012.

Nicholls, Robert Wyndham. The Jumbies' Playing Ground: Old World Influences on Afro-Creole Masquerades in the Eastern Caribbean. UP of Mississippi, 2012.

Regis, Helen A. "Blackness and the Politics of Memory in the New Orleans Second Line." American Ethnologist, vol. 28, no. 4, 2001, pp. 752-77.

---. "Second Lines, Minstrelsy, and the Contested Landscapes of New Orleans Afro-Creole Festivals." Cultural Anthropology, vol. 14, no. 4, 1999, pp. 472-504.

Roach, Joseph. Cities of the Dead: Circum-Atlantic Performance. Columbia UP, 1996.

Sakakeeny, Matt. Roll with It: Brass Bands in the Streets of New Orleans. Duke UP, 2013.

Schindler, Henri. Mardi Gras: New Orleans. Flammarion, 1997.

Simon, David, creator. Tremé. Blown Deadline Productions, 2006. HBO.

Szwed, John. Space is the Place: The Lives and Times of Sun Ra. Da Capo, 1997.

\section{Transcripts}

\section{Video 1}

"When the Saints"

Music playing (trumpet, drums, washboard)

People singing, "When the saints go marching in. Oh when the saints go marching in, oh when the saints go marching in..."

https://youtu.be/jjemiU6NTfQ

\section{Video 2}

"Keep that Lane Open"

Music playing off camera (drums, horns)

Person in wolf mask, waving a car down the street: "Keep that lane open! Keep that lane open!" https://youtu.be/v08LogaAsAU

\section{Video 3}

"Washboarding and Keeping That Lane Open"

Someone plays a washboard arhythmically as drums play in the distance.

Voice off camera: "Keep that lane open!"

https://youtu.be/LwsLgPH3fnk

\section{Video 4}

"Dancing in Front of the Parade"

Someone in jeans and a sport coat dances down the street as instrumental music (drums and horns) play off camera. https://youtu.be/iFN2aR580LI 


\section{Video 5}

"Under the Overpass"

Drums, voices, horns, and whistles louden and bounce off the ceiling of the overpass. People cheer, hoot, and whistle, drowning out the drums. As the camera moves from under the overpass, the sound dies down.

https://youtu.be/YgOIMAUnNyw 